\title{
PENGARUH TERAPI PSIKORELIGIUS TERHADAP PENURUNAN TINGKAT DEPRESI PADA LANSIA
}

\author{
Suryanti, Dwi Ariani S \\ Kementerian Kesehatan Politeknik Kesehatan Surakarta Jurusan Keperawatan
}

\begin{abstract}
Lower Extremity Elevation, Diabetic Ulcer Healing Process. People with Diabetes Mellitus have poor circulation, especially in areas far from heart, these causing the length of time of wounds healing. One of the interventions to improve the peripheral tissue perfusion of patients with Diabetic Ulcer is lower extremity elevation. The purpose of this research is describe the characteristics of respondents, knowing Diabetic Ulcer healing process without lower extremity elevation, knowing Diabetic Ulcer healing process with lower extremity elevation and knowing the effectiveness of Diabetic Ulcer healing without lower extremity elevation and with lower extremity elevation. This research is to design an quasy experiment non equivalent control group design and analysis data used Chi-Square test. Results of this research is the elevation of lower extremities more effectively to increased Ulcers Diabetic healing process. It's evidenced by Chi-Square test using Pearson Chi-Square analysis and obtained $\rho=$ 0,027 and $\alpha=0,05$. Elevation of lower extremities more effectively to increased Diabetic Ulcer healing in patients with Diabetic Ulcer in Melati I RSUD Dr. Moewardi. Lower extremity elevation expect can be applied in patients with Diabetic Ulcer.
\end{abstract}

Keywords : Lower Extremity Elevation, Diabetic Ulcer Healing Process.

Abstrak: Elevasi Ekstremitas Bawah, Proses Penyembuhan Ulkus Diabetik. Penderita Diabetes Melitus mempunyai sirkulasi yang buruk, terutama pada area yang jauh dari jantung, sehingga jika terjadi luka waktu penyembuhannya lama. Salah satu intervensi untuk memperbaiki perfusi jaringan perifer pasien dengan Ulkus Diabetik adalah elevasi ekstremitas bawah. Tujuan penelitian ini adalah mendeskripsikan karakteristik responden, mengetahui proses penyembuhan ulkus tanpa dilakukan elevasi ekstremitas bawah, mengetahui proses penyembuhan ulkus dengan dilakukan elevasi ekstremitas bawah dan mengetahui efektivitas penyembuhan ulkus tanpa dilakukan elevasi ekstremitas bawah dan dengan dilakukan elevasi ekstremitas bawah. Jenis penelitian ini adalah quasy experiment dengan model rancangan non equivalent control group design dan analisa data yang digunakan adalah uji Chi-Square. Hasil penelitian ini adalah elevasi ekstremitas bawah lebih efektif terhadap peningkatan penyembuhan Ulkus Diabetik. Hal ini dibuktikan dengan uji Chi-Square menggunakan analisis Pearson Chi-Square dan diperoleh nilai $\rho=0,027$ dan $\alpha=0,05$. Elevasi ekstremitas bawah lebih efektif terhadap peningkatan penyembuhan Ulkus Diabetik pada pasien dengan Ulkus Diabetik di Ruang Melati I RSUD Dr. Moewardi. Diharapkan elevasi ekstremitas bawah dapat diaplikasikan pada pasien dengan Ulkus Diabetik

Kata Kunci : Elevasi Ekstremitas Bawah, Proses Penyembuhan Ulkus Diabetik. 


\section{PENDAHULUAN}

Prevalensi penderita Ulkus Diabetik di Indonesia sekitar 15\% dengan risiko amputasi sebesar 30\%, angka mortalitas 32\% dan Ulkus Diabetik merupakan penyebab terbesar perawatan di rumah sakit yakni sebanyak $80 \%$. Penderita Ulkus Diabetik di Indonesia kurang lebih memerlukan biaya perawatan sebesar 1,3 juta sampai 1,6 juta rupiah setiap bulannya dan sekitar Rp 43,5 juta per tahun (Ridwan, 2011). Penurunan perfusi ke perifer menyebabkan nekrosis jaringan dan iskemik perifer sehingga berisiko terjadi Ulkus Diabetik. Gangguan perfusi tersebut akan menyebabkan abnormalitas aliran darah dimana kebutuhan nutrisi dan oksigen maupun pemberian antibiotik tidak mencukupi atau tidak dapat mencapai jaringan perifer dan atau untuk kebutuhan metabolisme pada lokasi tersebut sehingga membutuhkan perawatan Ulkus Diabetik yang benar (Suriadi, 2004).

Dasar dari perawatan Ulkus Diabetik meliputi 3 hal yaitu debridement, off loading dan kontrol infeksi (Kruse, 2006). Menurut Frykberg (2002), elevasi ekstremitas bawah merupakan manajemen Ulkus Diabetik tambahan yang bisa diterapkan. Elevasi ekstremitas bawah bertujuan agar sirkulasi perifer tidak menumpuk di area distal ulkus dan menyebabkan aliran darah akan cenderung menuju perifer terutama kaki yang mengalami ulkus. Edema akan meningkatkan tekanan area distal dan mengurangi perfusi akibat penekanan arterial, dengan elevasi ekstremitas bawah tekanan tersebut dapat dikurangi (Seeley, 2004). Penambahan manajemen Ulkus Diabetik dengan elevasi ekstremitas bawah diharapkan mampu mempercepat proses penyembuhan Ulkus Diabetik yang jumlah penderitanya besar di dunia.

Ruang Melati I RSUD Dr. Moewardi belum menambahkan elevasi ekstremitas bawah sebagai manajemen perawatan Ulkus Diabetik. Oleh karena itu, penulis tertarik untuk mengambil judul penelitian "Efektivitas Elevasi Ekstremitas Bawah terhadap Proses Penyembuhan Ulkus Diabetik di RSUD Dr. Moewardi Tahun 2014". Tujuannya adalah untuk mengetahui efektivitas elevasi ekstremitas bawah pada proses penyembuhan Ulkus Diabetik di ruang Melati I RSUD Dr. Moewardi.

\section{METODE PENELITIAN}

Jenis penelitian ini adalah Quasi eksperimen dengan design penelitian menggunakan One Group Pre and Post test Design. Pengambilan sampel dengan menggunakan teknik non probability sampling dengan cara purposive sampling di Panti Wredha Dharma Bakti Kasih Surakarta. Sample dilakukan pre test mengisi angket The Geriatric Depresion Scale (GDS), skala atau alat ukur ini adalah instrument yang disusun secara khusus digunakan lansia untuk mengukur tingkat depresi (Yesavage, Brink, dalam Kusharyadi, 2010). Kemudian dilakukan perlakuan berupa terapi psikoreligius, sebelum dilakukan terapi psikoreligius diawali dulu dengan mengkonsentrasikan pikiran klien dengan tehnik guide imagery, setelah perlakuan dilakukan test lagi untuk mengambil data post perlakukan. Analisa data dengan uji pairet $t$ test untuk membedakan nilai pretest postest pada kelompok perlakuan.

\section{HASIL PENELITIAN}

$\begin{array}{ccr}\text { Berdasarkan jenis } & \text { kelamin } \\ \text { kelompok intervensi } & \text { lebih } & \text { banyak }\end{array}$ 
responden dengan jenis kelamin laki-laki yakni sebesar $55,6 \%$, sedangkan pada kelompok kontrol jumlah antara responden laki-laki dan perempuan sama. Menurut Nogren (2007), penyebab yang sering mengakibatkan terjadinya Ulkus Diabetik adalah penyakit arteri perifer. Prevalensi penderita penyakit arteri perifer lebih banyak terjadi pada laki-laki dibandingkan dengan perempuan. Namun, hasil penelitian ini berbeda dengan hasil penelitian Purwanti (2013) bahwa responden dengan jenis kelamin perempuan lebih banyak dibandingkan laki-laki yaitu sebesar $64,7 \%$. Menurut Mayasari (2012) perubahan hormonal pada perempuan menopause akan meningkatkan risiko DM. Hal ini disebabkan karena perubahan hormonal dapat mempengaruhi sensitivitas sel-sel tubuh terhadap insulin, sehingga menopause dapat memperburuk kadar gula darah dan dapat menyebabkan komplikasi DM dari waktu ke waktu. Pada distribusi responden berdasarkan usia kelompok intervensi lebih banyak responden dengan usia $\geq 50$ tahun yakni sebesar $66,7 \%$, begitu pula dengan kelompok kontrol yakni sebesar 66,7\%. Menurut Prastica (2013) Ulkus Diabetikum dapat terjadi pada usia $\geq 50$ tahun, hal ini disebabkan karena fungsi tubuh fisiologis menurun seperti penurunan sekresi atau resistensi insulin, sehingga kemampuan fungsi tubuh terhadap pengendalian glukosa darah yang tinggi kurang optimal. Kadar gula darah yang tidak terkontrol akan mengakibatkan komplikasi kronik jangka panjang, baik makrovaskuler maupun mikrovaskuler salah satunya Ulkus Diabetik. Penelitian Sugiarto (2013) juga menunjukkan bahwa responden dengan usia $\geq 50$ tahun lebih rentan terkena Ulkus Diabetik. Dalam penelitian tersebut terdapat 23 respoden $(79,3 \%)$ berusia $\geq 50$ tahun menderita Ulkus Diabetik dan terdapat hubungan yang signifikan antara usia terhadap terjadinya ulkus dengan risiko 18 kali lebih besar menderita Ulkus Diabetik dibandingkan dengan usia $<50$ tahun.

Sedangkan berdasarkan lamanya menderita DM pada kelompok intervensi responden dengan lama menderita $\mathrm{DM} \geq 8$ tahun paling banyak yaitu sebesar $66,7 \%$, sama halnya dengan kelompok kontrol yakni sebesar 77,8\%. Menurut Bararbutar (2012), penderita dengan lama $\mathrm{DM} \geq 8$ tahun mempunyai risiko besar terjadinya komplikasi, salah satunya adalah neuropati diabetik. Neuropati sensorik menyebabkan kerusakan pada saraf yang menyebabkan saraf tidak dapat merespon rangsangan dari luar. Hilangnya sensasi perasa pada penderita DM menyebabkan penderita tidak dapat menyadari bawah ekstremitasnya terluka dan menimbulkan terjadinya ulkus. Hasil penelitian yang dilakukan Ira (2014) juga menunjukkan adanya hubungan yang signifikan antara lama menderita DM dengan risiko terjadinya ulkus Diabetik. Berdasarkan penelitian tersebut didapatkan bahwa responden dengan lama menderita $\mathrm{DM} \geq 8$ tahun mendominasi, yakni sebanyak 21 responden $(58,3 \%)$. Dapat disimpulkan bahwa semakin lama menderita DM maka semakin tinggi pula risiko terjadinya Ulkus Diabetik, sehingga penderita DM harus melakukan penatalaksanaan DM dengan baik agar risiko tersebut dapat diturunkan.

Tabel 1

Efektivitas Elevasi Ekstremitas Bawah Antara Kelompok Intervensi dan Kelompok Kontrol( $(n=36)$ 


\begin{tabular}{|c|c|c|c|c|c|}
\hline Variabel & $\begin{array}{l}\text { Membaik } \\
\text { (skor } \\
\text { turun) }\end{array}$ & $\begin{array}{l}\text { Tetap } \\
\text { (skor } \\
\text { tetap) }\end{array}$ & $\begin{array}{l}\text { Memburuk } \\
\text { (skor naik) }\end{array}$ & Total & pvalue \\
\hline $\begin{array}{l}\text { Kelompok } \\
\text { Intervensi }\end{array}$ & 16 & 2 & 0 & 18 & $\rho=$ \\
\hline $\begin{array}{l}\text { Kelompok } \\
\text { Kontrol }\end{array}$ & 9 & 5 & 4 & 18 & 0,027 \\
\hline Total & 25 & 7 & 4 & 36 & \\
\hline
\end{tabular}

Pearson Chi Square didapatkan derajat kebebasan $(\mathrm{df})=2$, tingkat signifikan $(\alpha)$ $=0,05$ karena ada sel $\leq 5$, serta didapatkan nilai $\rho=0,027$. Dari hasil tersebut didapatkan bahwa nilai $\rho<0,05$ sehingga Ho ditolak yang berarti bahwa pemberian elevasi ekstremitas bawah lebih efektif terhadap peningkatan proses penyembuhan Ulkus Diabetik dibandingkan dengan tanpa diberikan elevasi ekstremitas bawah. Menurut Frykberg (2002), salah satu hal yang sangat penting namun kurang mendapatkan perhatian dalam perawatan ulkus kaki diabetik adalah mengurangi atau menghilangkan beban pada kaki. Metode sederhana yang dapat dilakukan adalah dengan elevasi ekstremitas bawah. Tindakan tersebut akan memperbaiki sirkulasi darah pada perifer serta mengurangi edema pada ekstremitas bawah. Perfusi jaringan perifer yang maksimal pada ulkus akan membuat proses penyembuhan ulkus lebih cepat.

Menurut Seeley (2004), elevasi ekstremitas bawah berguna untuk mengembalikan aliran darah dan mengurangi tekanan di bagian distal ekstremitas. Aktivitas lebih dari 15 menit dapat meningkatkan tekanan ke area distal sebesar $20 \%$, dengan elevasi ekstremitas bawah tekanan tersebut dapat dikurangi dan perfusi jaringan perifer dapat diperbaiki. Penambahan manajemen Ulkus Diabetik dengan elevasi ekstremitas bawah diharapkan mampu mempercepat proses penyembuhan Ulkus Diabetik yang jumlah penderitanya besar di dunia.

Hasil penelitian yang dilakukan oleh Wulandari et al (2010) tentang pengaruh elevasi ekstremitas bawah terhadap penyembuhan Ulkus Diabetik sependapat dengan hasil penelitian ini. Dari hasil observasi yang dilakukan menunjukkan adanya perbaikan proses penyembuhan ulkus yang lebih cepat terutama pada kelompok intervensi, walaupun pada setiap kelompok mengalami perubahan skor healing index.

Penelitian Kurniawan (2011) juga menunjukkan hasil yang sependapat dengan penelitian ini. Pada penelitian ini didapatkan nilai $\mathrm{p}=0,001$ dan $\alpha=0,05$ yang menunjukkan adanya proses penyembuhan luka signifikan. Lembar observasi yang digunakan yaitu LUMT (Leg Ulcers Measurement Tool) dan penelitian ini tidak menggunakan kelompok kontrol. Edema pada kstremitas bawah mengalami penurunan dan penyembuhan ulkus mengalami banyak kemajuan. Metode elevasi ekstremitas bawah ini dapat digunakan sebagai intervensi untuk mengurangi beban atau tekanan pada ekstremitas bawah.

\section{PEMBAHASAN}

Terapi psikoreligius merupakan bagian dari terapi kognitif- perilaku. Terapi psikoreligius merupakan suatu pengobatan alternatif dengan cara pendekatan keagamaan melalui doa dan dzikir yang merupakan unsur penyembuh penyakit (Rozalino R, 2009). Sebagai mahkluk ciptaan Tuhan kita diwajibkan untuk berbakti padaNya, tetapi terkadang kita tidak menjalankan secara maksimal atau Khusuk karena lemahnya keimanana, keterbatasan waktu dan situasi yang tidak 
mendukung. Dengan terapi psikoreligius yang pelaksanaanya diawali dengan guide imagery (imajinasi terbimbing) diharapkan pasien akan lebih berfokus, agar doa yang dilaksanakan semakin khidmat atau khusuk, karena jika dilaksanakan secara lebih maksimal atau khusuk tindakan ini akan lebih efektif dalam menurunkan depresi.

Penelitian tentang pengaruh psikoreligius terhadap penurunan depresi pada pasien di Panti Wredha Dharma Bakti Kasih Surakarta 2015. Hasil penelitian dan interprestasinya adalah Berdasarkan table 4.3 bahwa setelah dianalisa dengan uji $t$, dapat digambarkan bahwa perbedaan nilai rata-rata score tingkat depresi sebelum dan sesudah perlakukan terapi psikoreligi mengalami penurunan yang signifikan dari 30,87 menjadi 9,07 (t hitung 21,8) dan $\mathrm{P}$ value $0,000<\alpha(0,05)$ artinya bahwa terapi psikoreligius mempunyai pengaruh yang sangat signifikan dalam menurunknan derajat depresi pada lansia. Setelah dilakukan terapi psikoreligius dengan do'a dan dzikir pasien merasa senang, nyaman di panti, dan lain-lain. Hal ini menunjukkan adanya perubahan respon emosional.

Respon emosional yang positif atau dari pengaruh Terapi psikoreligius dengan Doa dan dzikir ini berjalan dalam tubuh kemudian diterima oleh batang otak, yakni thalamus. Thalamus menstransmisikan impuls hipokampus (pusat memori untuk mengkoordinasikan segala hal yang diserap indera) untuk mensekresikan GABA (Gama Amino Batiric Acid) yang bertugas sebagai pengontrol respon emosi, dan menghambat asetylcholine, serotonis dan neurotransmiter yang lain yang memproduksi sekresi kortisol, sehingga akan terjadi proses homeostasis (keseimbangan) yang akan memperbaiki sistem neurotransmitter yang terganggu dan memunculkan optimisme, dan menghilangkan pikiran negatif, sehingga akan memunculkan pikiran-pikiran yang positif.

Tubuh manusia yang tenang, yang selalu berpikiran positif, maka tubuh akan bekerja dengan ketaatan beribadah, lebih mendekatkan diri kepada Allah SWT dan pandai bersyukur sehingga tercipta suasana keseimbangan dari neurotransmitter yang ada di dalam otak.

Efek ketenangan berdo'a dan berzikir mampu meningkatkan proses regenerasi sel syaraf ketika terjadi perbaikan kondisi sistem syaraf pusat dan spinal cord. Hal ini akan memperlancar proses pada cerebral cortex yang akan bereaksi terhadap keseimbangan bio-kimia tubuh.

Di samping itu berdo'a dan berzikir secara khusyuk akan menyeimbangkan kondisi bio-elektrik pasien. Bio-elektrik dan neurotransmitter menjadi seimbang yang selanjutnya berefek pada optimalisasi kinerja organ tubuh secara keseluruhan dan menciptakan kemampuan tubuh untuk menyembuhkan diri sendiri (Hembing Wijayakusuma Mawardi el Shulthoni, 2002; Zainul, 2007).

Pendekatan keagamaan dalam praktek kedokteran dan keperawatan dalam dunia kesehatan, bukan untuk tujuan mengubah keimanan seseorang terhadap agama yang diyakininya, melainkan untuk membangkitkan kekuatan spiritual dalam menghadapi penyakit. Dengan terapi psikoreligius akan melakukan kontrol terhadap emosi yang mempengaruhi proses pikir serta ketegangan otot (Stuart \& Sunden, 2000). 
Hal ini telah dibuktikan dalam hasil penelitian, bahwa setelah diberi terapi psikoreligius mengalami perubahan signifikan dibandingkan sebelum di beri terpai psikoreligius. Dengan demikian terapi psikoreligius mempunyai pengaruh terhadap penurunan depresi pada lansia di di Panti Wredha Dharma Bakti Kasih Surakarta.

\section{KESIMPULAN DAN SARAN}

Elevasi ekstremitas bawah lebih efektif terhadap peningkatan proses penyembuhan Ulkus Diabetik dibandingkan dengan tanpa diberikan elevasi ekstremitas bawah, hal ini berdasarkan pada analisis Pearson Chi Square dengan nilai $\rho=0,027$, tingkat signifikan $(\alpha)=0,05$, derajat kebebasan $(\mathrm{df})=2$. Saran untuk penelitian ini adalah diharapkan pada penelitian selanjutnya dapat melakukan penelitian yang lebih kompleks seperti penambahan variabelvariabel perancu misalnya status nutrisi pasien, kadar glukosa dalam darah, obatobatan, status psikologis pasien, jumlah sampel yang lebih banyak dan metode penelitian yang berbeda. Elevasi ekstremitas bawah ini diharapkan bisa menjadi salah satu metode perawatan pasien dengan Ulkus Diabetik untuk mempercepat proses penyembuhan ulkus.

\section{DAFTAR RUJUKAN}

Frykberg Robert G. (2002). Risk Factor, Pathogenesis and Management of Diabetic Foot Ulcers, Des Moines University, Iowa.

Kruse I, Edelman S. (2006). Evaluation and Threatment of Diabetic Foot Ulcer. Inggris : Clinical Diabetes Vol24, Number 2.

Mayasari, L. (2012/. Wanita Menopause lebih Berisiko Diabetes Mellitus.
Diperoleh dari www.health.detik.com, diakses pada Mei 2014.

Prastica V.A. (2013). Perbedaan Angka Kejadian Ulkus Diabetikum Pada Pasien Diabetes Melitus dengan dan tanpa Hipertensi di RSUD Dr. Saifudin Anwar Malang. Tugas akhir. Malang : Universitas Brawijaya.

Purwanti, O.S. (2013). Analisis FaktorFaktor Risiko Terjadi Ulkus Kaki Pada Pasien Diabetes Melitus di RSUD Dr. Moewardi. Skripsi. Jakarta : Universitas Indonesia.

Wulandari, Yetti, Hayati. (2010). Pengaruh Elevasi Ekstremitas Bawah terhadap Proses Penyembuhan Ulkus Diabetik. Diperoleh dari http://lontar.ui.ac.id/file?file=pdf/, diakses tanggal 18 September 2013.

Sugiarto, I. (2013). Faktor Resiko yang berhubungan dengan Terjadinya Ulkus Diabetik pada Pasien Diabetes Mellitus Tipe 2 di RSUD Dr. Margono Soekarjo Purwokerto. Skripsi. Purwokerto: Universitas 